\title{
Combined therapy of somatostation anallogues and dopamine agonists in the treatment of pituitary tumours
}

\author{
Annamaria Colao, Mariagiovanna Filippella ${ }^{1}$, Rosario Pivonello, Carolina Di Somma, Antongiulio Faggiano and \\ Gaetano Lombardi \\ Department of Molecular and Clinical Endocrinology and Oncology, 'Federico II' University of Naples, via S. Pansini 5, 80131 Naples, Italy and ${ }^{1}$ Unit of \\ Diabetology and Endocrinology, Hospital of Aosta, Aosta, Italy \\ (Correspondence should be addressed to A Colao; Email: colao@unina.it)
}

\begin{abstract}
Pituitary tumours express both somatostatin and dopamine receptors. Medical treatment with somatostatin analogues is a cornerstone of $\mathrm{GH}$ - and TSH-secreting tumours, while treatment with dopamine agonists is a cornerstone of prolactin-secreting tumours. Dopamine agonists have also demonstrated some efficacy in patients with GH- and TSH-secreting adenomas. Neither ACTHsecreting nor clinically non-functioning tumours have a well-established medical treatment. Nevertheless, some recent results have indicated a potential usefulness of the dopamine agonist cabergoline in patients with pituitary-dependent Cushing's disease. Combination treatment with both somatostatin analogues and dopamine agonists has been poorly investigated. Some studies conducted in small series have documented an additive effect of both drugs in patients with GH-secreting adenomas. Of mention is that none of the studies were randomised and cross-sectional so that the results should be confirmed by other well-designed studies. No data are available in other pituitary tumour histotypes. Preliminary observations in patients with clinically non-functioning adenomas are very promising.
\end{abstract}

European Journal of Endocrinology 156 S57-S63

\section{Introduction}

The somatostatin and dopamine systems constitute two major neurotransmitter networks that share a number of structural and functional features. The various actions of somatostatin and dopamine are mediated by five specific receptor subtypes: sst $_{1}-\mathrm{sst}_{5}$ and $\mathrm{D}_{1}-\mathrm{D}_{5}$ respectively. Two different isoforms of $s t_{2}$ and $D_{2}$ have been found and characterised. The different somatostatin and dopamine receptors have variable organ-, tissue- and cytospecific distribution and play different physiological roles $(1,2)$. Somatostatin receptors have been demonstrated to be highly expressed in pituitary adenomas, with a predominance of $\mathrm{sst}_{2}$ and $\mathrm{sst}_{5}$ and infrequent expression of $s_{4}(3-8)$. The expression of sst $_{2}$ predicts a response to octreotide and lanreotide, the two somatostatin analogues most widely used in clinical practice which show high affinity for sst ${ }_{2}$ and sst $_{5}$ and low affinity for $\operatorname{sst}_{3}(9,10)$.

This paper was presented at a symposium held at the Erasmus Medical Center, Rotterdam, The Netherlands, 2005. The symposium was jointly organized by LJ Hofland, Erasmus Medical Center, and A Colao, Federico II University of Naples, Italy. Ipsen partially supported the publication of these proceedings.
The $\mathrm{D}_{2}$ receptor has been clearly demonstrated in both prolactin (PRL)-secreting (5) and non-PRL-secreting pituitary tumours $(6,7-11)$, and its presence and intensity of expression predict a response to treatment with dopamine agonists. Moreover, $\mathrm{D}_{2}$ has been found in thyrotrophin (TSH)- and follicle-stimulating hormone/ luteinising hormone-secreting pituitary tumours, although treatment with dopamine agonists is still debated in patients bearing these tumours because of a low density of $\mathrm{D}_{2}$ or different distribution of $\mathrm{D}_{2}$ isoforms compared with prolactinomas $(12,13)$. More recently, expression of $D_{2}$ receptors has been found also in adrenocorticotrophin (ACTH)-secreting pituitary adenomas and, interestingly, the $D_{2}$ receptor expression was found to be correlated with the short-term response to cabergoline (14). Among the different dopamine agonists, cabergoline has been demonstrated to be the most effective in controlling hormonal hypersecretion and inhibiting tumour growth in pituitary tumours (12-14).

Furthermore, a functional interaction between $\mathrm{D}_{2}$ and sst $_{5}$ receptors has recently been reported (15), suggesting a potential benefit from the combined targeting of these receptors.

The use of a combined somatostatin analogue and dopamine agonist treatment schedule seems to be of particular interest in growth hormone (GH)-secreting 
adenomas that are known to be potentially responsive to both classes of compounds (16-25). More recently, nonfunctioning pituitary adenomas were shown to be sensitive to a combined treatment, whereas the response rate to somatostatin analogues or dopamine agonists alone is limited. No study with combined therapy has so far been reported in PRL- and ACTH-secreting adenomas, and no rationale exists today for such an approach with the presently available somatostatin analogues.

This review focuses on literature data reporting on the results of combined somatostatin analogues (octreotide or lanreotide) plus dopamine agonists (bromocriptine or cabergoline) in patients bearing $\mathrm{GH}$-secreting or clinically non-functioning pituitary tumours.

\section{GH-secreting tumours}

Several groups have investigated the possible therapeutic role of a combination therapy of somatostatin analogues and dopamine agonists in the inhibition of GH and insulin-like growth factor-I (IGF-I) levels in acromegalic patients. Before octreotide was introduced, bromocriptine was the only available medical therapy for acromegaly (26). Bromocriptine was shown to suppress random growth hormone levels to $<10 \mu \mathrm{g} / \mathrm{l}$ in $50 \%$ of patients, but IGF-I levels normalise in only $10 \%$ of treated patients and $<20 \%$ of GH-secreting tumours were reported to reduce in size (26). The subjective clinical symptoms improved in $70-90 \%$ of patients (26). Quinagolide, another dopaminergic agent, at a dose of $0.3-0.6 \mathrm{mg} /$ day suppressed GH and IGF-I levels to normal in about $30 \%$ of the treated patients (16). More impressive results were obtained using cabergoline, a long-lasting $\mathrm{D}_{2,4}$-selective dopamine agonist. In a large series of 64 patients, treatment with cabergoline suppressed plasma IGF-I below $300 \mu \mathrm{g} / \mathrm{l}$ in $39 \%$ of cases and between 300 and $450 \mu \mathrm{g} / \mathrm{l}$ in another $28 \%$; in GH/PRL-co-secreting adenomas $(n=16) 50 \%$ of cases suppressed IGF-I levels below $300 \mu \mathrm{g} / \mathrm{l}$, and another $31 \%$ did so between 300 and $450 \mu \mathrm{g} / \mathrm{l}$, in contrast to only 35 and $27 \%$ respectively in pure GH-secreting adenomas (27). Additionally, tumour shrinkage was demonstrated in 13 out of 21 patients, with an $\approx 50 \%$ mass reduction in five GH/PRLco-secreting adenomas (27). Data were less impressive in our study showing that cabergoline did not normalise GH or IGF-I levels in 11 patients with GH-secreting tumours treated with $1 \mathrm{mg}$ twice a week (16). Increase of the dose up to $0.5 \mathrm{mg} /$ day was associated with suppressed GH and decreased tumour size (28).

Somatostatin analogues were introduced as an effective therapy for acromegaly $\approx 20$ years ago. In a recent meta-analysis (29), it was reported that both depot formulations of somatostatin analogues, namely octreotide-LAR and lanreotide, are effective in 50-75\% of patients with acromegaly. When given as first-line treatment, somatostatin analogues induce tumour shrinkage by $>20 \%$ in $80 \%$ of patients (29). This implies that 25 to $50 \%$ of the patients, in different series, do not fully respond to somatostatin analogues.

Combined treatment with octreotide and bromocriptine was initially observed to have an additive effect on GH and IGF-I suppression in patients with acromegaly when compared to treatment with either drug alone $(16,17,30)$. The bioactivity of bromocriptine increases when administered alongside octreotide (17). In vitro studies highlighted that both bromocriptine and octreotide at high doses are able to inhibit cell growth from human somatotroph adenomas (18). A dose of $1 \mathrm{nmol} / \mathrm{l}$ bromocriptine decreased cell growth in $40 \%$ of somatotroph cell cultures, whereas $10 \mu \mathrm{mol} / \mathrm{l}$ decreased cell counts in all somatotrophs and in $92 \%$ of non-functioning adenoma cultures. Both 1 and $10 \mu \mathrm{mol} / \mathrm{l}$ octreotide significantly decreased cell counts in $50 \%$ of somatotroph cell cultures.

Subsequent in vivo studies have confirmed that the combination of somatostatin analogues and dopamine agonists is more effective than somatostatin analogues alone in reducing $\mathrm{GH}$ levels in patients with GH-secreting adenomas resistant to somatostatin analogues (17, 19-25).

In 51 acromegalic patients, acute co-administration of bromocriptine $(2.5 \mathrm{mg})$ and octreotide $(0.05 \mathrm{mg})$ had an additive suppressive effect on $\mathrm{GH}$ hypersecretion (19). In particular, GH levels were $<2$ and $5 \mu \mathrm{g} / \mathrm{l}$ in 32 and $56 \%$ of acromegalic patients respectively. GH levels decreased by more than $50 \%$ in $84 \%$ of patients (19). The combination of more potent dopamine agonists, such as cabergoline, with a depot preparation of somatostatin analogues, such as lanreotide, allowed us to achieve normalisation of IGF-I levels in five out of ten cases (23). Figure 1 shows the individual GH and IGF-I levels before and during different treatment schedules of these ten patients previously reported.

In contrast with these findings, Fredstorp et al. did not find any difference between octreotide alone and octreotide plus bromocriptine therapy in reducing $\mathrm{GH}$ levels in acromegalic patients (31).

In vivo and in vitro experiments were performed to evaluate the anti-secretive activity of somatostatin and dopamine analogues in four patients bearing mixed GH/PRL-secreting tumours, and data were correlated with the results of in vivo somatostatin and dopamine receptor scintigraphy and with immunohistochemical findings (32). These patients, presenting similar clinical findings and comparable peripheral hormone levels. showed different responsiveness to somatostatin and dopamine analogues. Moreover, primary tumour cell culture experiments showed that octreotide and dopamine had an inhibiting activity on GH and PRL secretion, which was positively correlated with the response observed in vivo. In another study, Zatelli et al. (33) investigated $\mathrm{D}_{2}$, sst $_{2}$ and sst ${ }_{5}$ receptor expression in 24 GH-secreting pituitary adenomas and tested the effects of somatostatin agonists selectively interacting with sst $_{2}$ (BIM-23 120) 

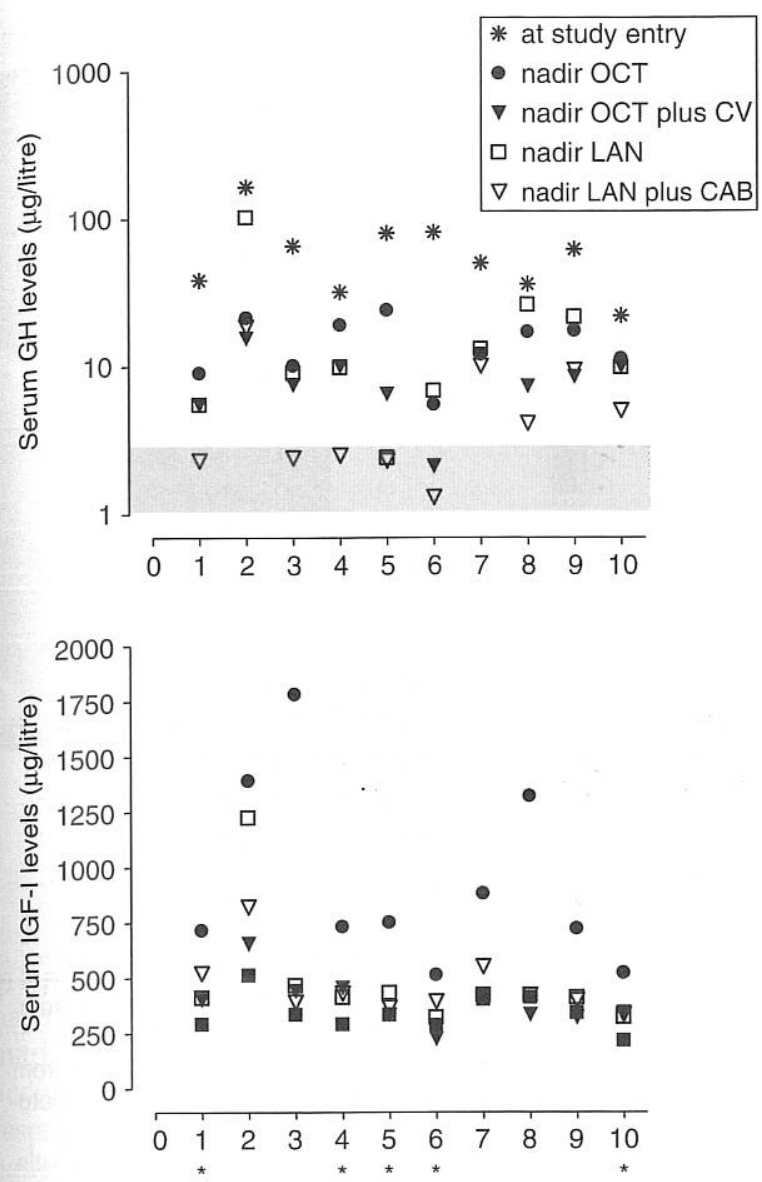

Figure 1 Serum GH levels (top) and serum IGF-I levels (bottom) in ten patients with resistant acromegaly. Data are derived from ref. 22. The patients were initially treated with subcutaneous octreotide (OCT; Sandostatina, Novartis, Italy) at a starting dose of $0.3 \mathrm{mg} /$ day over three doses, increased up to $0.6 \mathrm{mg} /$ day after 1 month, to achieve normalisation of GH and IGF-I levels. After 6 months, quinagolide (CV; kindly provided by Novartis, Italy) was added for 3 months at a dose of $0.3 \mathrm{mg}$ twice daily, because GH and IGF-I were not suppressed. Due to the unresponsiveness to the combination scheme intramuscular lanreotide (LAN; Ipstyl, Ipsen, Milan, Italy) treatment was initiated, after 15-30 days wash-out from OCT + CV treatment, at a dose of $30 \mathrm{mg}$ at 14-day intervals for 3 months and then at 10-day intervals in all patients. After a 6-month treatment, cabergoline (CAB; Dostinex, Pharmacia\&Upjohn, Italy) was added at a dose of $1.5 \mathrm{mg}$ per week ( $0.5 \mathrm{mg}$ three times a week) for the first month and then at a dose of $3.5 \mathrm{mg}$ per week $(0.5 \mathrm{mg}$ daily) for another 2 months. At the end of the study five of ten patients achieved control of GH and/or IGF-I levels. Normal GH levels are in the grey area $(\leq 2.5 \mu \mathrm{g} /$ litre) while normal IGF-I levels for age and gender are marked by an asterisk.

and sst 5 (BIM-23 206) on GH secretion in primary culture. GH secretion was inhibited by BIM-23 120 in all samples, while it was reduced by BIM-23 206 only in adenomas not expressing $\mathrm{D}_{2}$. These results suggest that adenomas expressing $\mathrm{D}_{2}$ are less likely respond to the clinically available somatostatin analogues in terms of inhibition of GH secretion (33).

In summary, a few studies reported an additive effect of dopamine agonists (mainly cabergoline) to that of somatostatin analogues on suppressing GH and IGF-I levels. Though experimental data support these clinical observations, the combined treatment with depot somatostatin analogues plus dopamine agonists is not routinely applied to patients partially responsive to somatostatin analogues. A recruitment bias of previous studies is the inclusion of most patients with concomitant hyperprolactinaemia. More recently, Cozzi et al. (24) reported that the addition of cabergoline, using the minimal effective and the maximal tolerated dose (range $1-3.5 \mathrm{mg} /$ week), significantly decreased GH and IGF-I levels after 6 months (Fig. 2); in this study, results were not dependent on PRL status (serum levels or immunohistochemistry). The combined treatment decreased GH to $<2.5 \mu \mathrm{g} / \mathrm{l}$ in $21 \%$ of 19 patients and normalised IGF-I for age in $42 \%$ of patients (24).

Therefore, randomised, prospective, controlled studies are required to confirm the beneficial effect of a combined treatment of somatostatin analogues plus dopamine agonists in acromegaly.

\section{Non-functioning pituitary adenomas}

Clinically non-functioning adenomas (NFA) represent a very heterogeneous group of pituitary tumours, accounting for $25 \%$ of all pituitary adenomas (34).

Presently, there is no established role for pharmacotherapy in NFA. There is a rationale for both dopamine agonists and somatostatin analogues in the treatment of NFA in accordance with in vitro and in vivo evidence of dopamine and somatostatin receptor expression in this adenoma histotype $(7,35-42)$. However, the results of bromocriptine, quinagolide (36-40) and octreotide treatment (43-46) were disappointing in almost all studies, except for some case reports.

The majority of studies on dopamine agonists in these tumours were performed with bromocriptine, which inhibited hormone secretion in vitro and in vivo in a consistent percentage of cases but inhibited in vitro tumoural cell growth and reduced in vivo tumoural mass only in a minority of patients $(7,36,37,47)$. In particular, bromocriptine sporadically induced tumour shrinkage only by using high doses of drug. A few studies have investigated the efficacy of quinagolide in the treatment of these tumours. Quinagolide induced a short-term inhibition of gonadotrophins and/or $\alpha$-subunit secretion in $80 \%$, tumour shrinkage in $20 \%$ and tumour stabilisation in $60 \%$ of cases (48). The higher efficacy of quinagolide compared to bromocriptine in reducing pituitary tumour mass in a 39-year-old woman was also demonstrated (39). On the other hand, pituitary tumour uptake at scintigraphy with radiolabelled dopamine analogue, $\left[{ }^{123} \mathrm{I}\right]$-methoxybenzamide, was predictive of hormone inhibition and tumour shrinkage in patients with clinically non-functioning pituitary tumours (49). Moreover, cabergoline treatment 

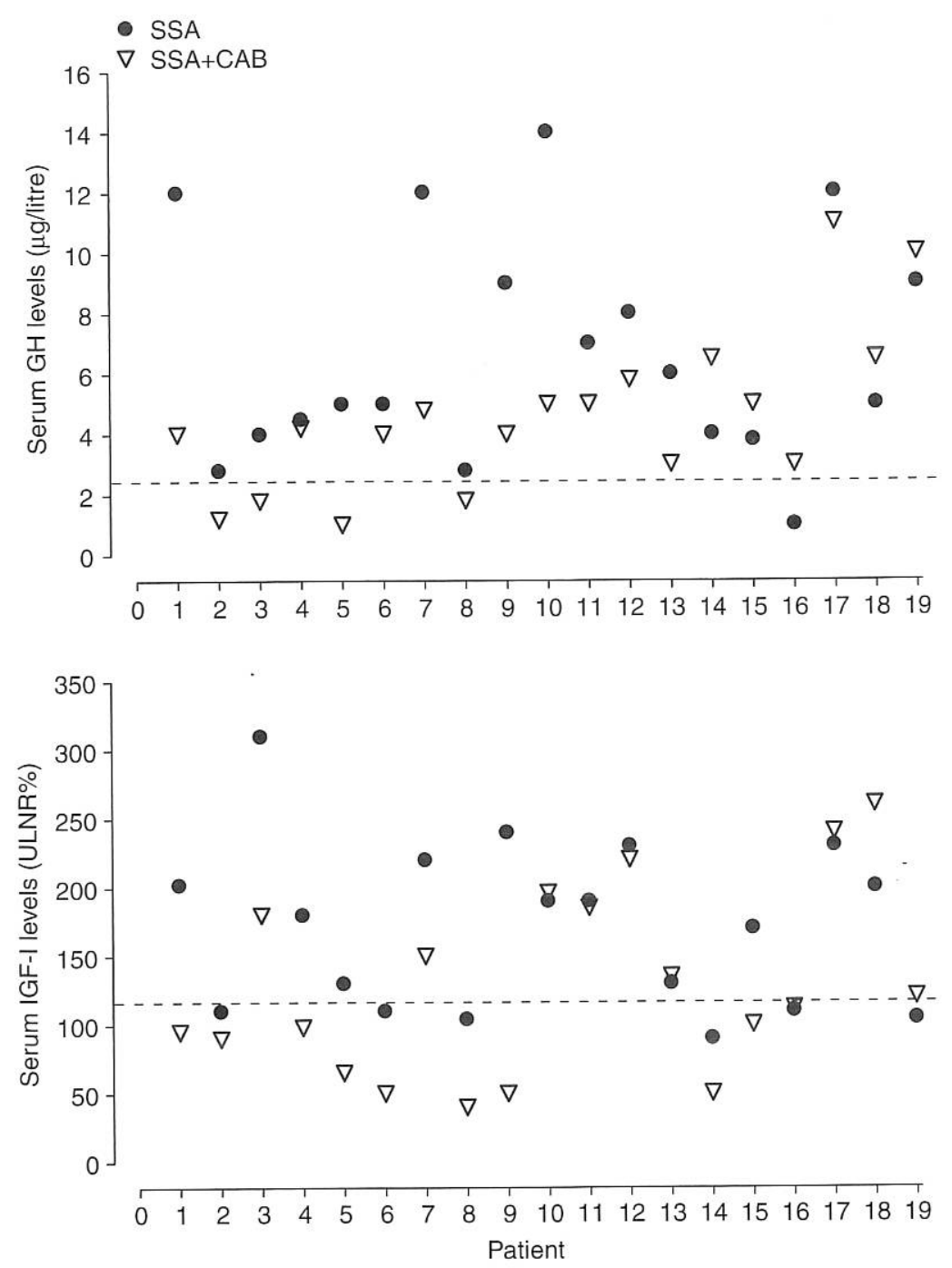

Figure 2 Serum GH levels (top) and serum IGF-I levels (bottom) in 19 patients with resistant acromegaly. Data are derived from ref. 23. The patients were receiving somatostatin analogue therapy and without any change in dose or schedule of somatostatin analogue treatment, cabergoline (CAB; Pharmacia) was started at $0.25 \mathrm{mg}$ during evening meal twice a week for 2 weeks. The dose was then progressively up-titrated, adding $0.25 \mathrm{mg}$ every week until the dose of $0.25 \mathrm{mg}$ four times weekly was reached or side-effects occurred. This dose was administered for 1 month.

has recently been demonstrated to induce tumour shrinkage: 7 out of 13 patients had tumour shrinkage above $10 \%$ of the initial volume and four patients achieved an increasing distance of the tumour from the optic chiasm because of shrinkage (50). Additionally, two out of nine patients with visual field defects before therapy showed improvements in visual acuity during cabergoline treatment (50). These data suggested improved effectiveness of cabergoline over bromocriptine in the treatment of this category of pituitary tumours as well (50). Another recent study demonstrated that 1 year of cabergoline treatment at the dose of $3 \mathrm{mg} /$ week induced more than $25 \%$ tumour shrinkage in $56 \%$ of patients with clinically non-functioning tumours (51). In this study, tumour shrinkage by cabergoline treatment was accompanied by a significant correlation with $\mathrm{D}_{2}$ receptor expression (51). Some degree of tumour shrinkage was also noted during cabergoline treatment; greater tumour shrinkage was observed in patients with expression of mRNA $D_{2}$ receptors on their tumour membrane surfaces (Fig. 3).
Somatostatin analogues represent another category of drugs used in the medical treatment of NFA. Their utilisation in NFA was justified by the evidence of sst receptor expression in these tumours. The reduction in tumour volume during octreotide treatment has been reported in a few NFA-bearing patients. Liuzzi et al. (52) reported tumour reduction in $15 \%$ of 20 patients and Plockinger et al. (44) reported in 50\% of four patients. Warnet et al. (46) reported a tumour mass decrease in two NFA patients who undergone shortterm octreotide treatment.

The presence of both somatostatin and dopamine receptors in NFA suggests the possibility of treating these tumours with somatostatin and dopamine agonists $(37-40,44,45,52-55)$. As already mentioned, a functional interaction between $\mathrm{D}_{2}$ and sst ${ }_{5}$ receptors has recently been reported (15), supporting a potential benefit from combined use of these two categories of compounds. In a recent study, the effect of combination therapy with octreotide and cabergoline was investigated 
Case 3

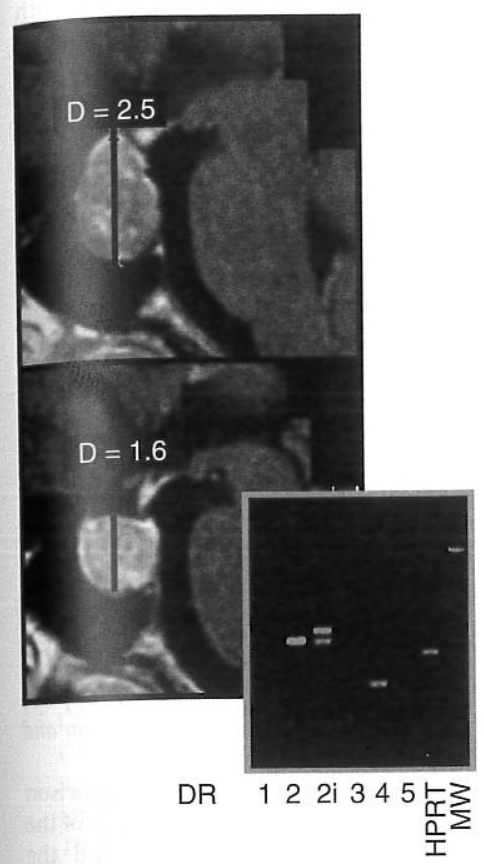

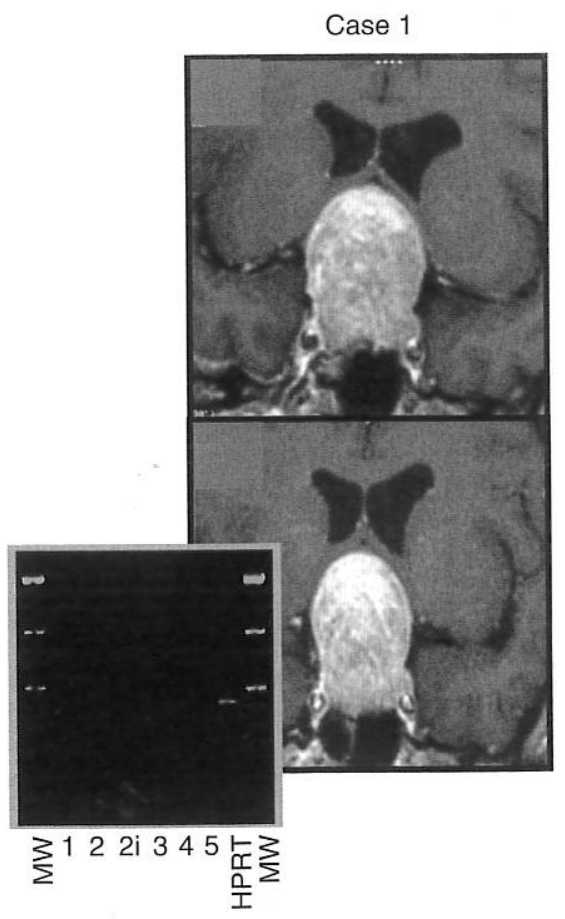

Figure 3 Exemplary cases of tumour mass change after 1 year of cabergoline treatment and comparison with the expression of dopamine receptor in the tumour as evaluated at the RT-PCR study. DR, dopamine receptor; $\mathrm{D}_{2} \mathrm{i}, \mathrm{D}_{2}$ receptor isoforms $\left(D_{2 \text { short }}\right.$ and $\left.D_{\text {2long }}\right)$; MW, molecular weight. Case 1 represents a case not responsive to cabergoline with a maximal diameter reduction of $0 \%$ and a tumour volume increase of $4 \%$ of baseline; the RTPCR shows no expression of any dopamine receptor in the tumour. Case 3 represents a case responsive to cabergoline with a maximal diameter reduction of $36 \%$ and a tumour volume decrease of $52 \%$ of baseline; the RT-PCR shows the expression of $D_{\text {2long, }}, D_{2 \text { short }}$ and $D_{4}$ in the tumour. Data drawn from Ref. 51 with permission of the Endocrine Society. in ten patients with NFA (55). Tumour shrinkage $>10 \%$ has been reported in six out of ten patients. However, markedly high doses of octreotide and cabergoline, accounting for $200 \mu \mathrm{g} \times 3 /$ day and $0.5 \mathrm{mg} /$ day respectively, had been employed. Recent studies on patients with NFA treated with somatostatin analogues have shown a rapid improvement of the visual field in most cases $(56,57)$.

On the basis of these data, combined therapy can be an efficacious and safe schema in the treatment of NFA, since it enables induction of remnant tumour shrinkage in most of the patients who previously undergone surgery, together with a marked improvement in visual function. Unfortunately, to date, no studies have been reported using modern somatostatin analogues in combination with cabergoline to respond to this hypothesis.

\section{Conclusion}

Pituitary tumours express both somatostatin and dopamine receptors with a pattern that differs according to different tumour histotypes. Treatment with dopamine agonists is characteristically effective in PRLsecreting tumours, but GH-, TSH-, ACTH-secreting tumours and NFA may also show some degree of efficacy. Treatment with somatostatin analogues is effective particularly in GH-secreting tumours, but also in TSH-secreting tumours and (much less) in NFA. The combination treatment with both drug classes has been shown in a few studies of clinical relevance in GH-secreting adenomas and NFA. Further studies with the new selective analogues and the new chimeric compounds will further enlarge the possibility to treat pituitary tumours using a medical approach.

In particular, the use of the so-called universal ligand, SOM230, which is able to bind with high affinity to the sst $_{1-3}$ and sst $_{5}$, either alone or in combination with cabergoline or other selective $\mathrm{D}_{2}$ agonists, would probably be of use in treating more patients with resistant pituitary and (potentially) neuroendocrine tumours. The preliminary data of SOM230 in acromegaly (58) and Cushing's disease (59) are very promising, but further studies are needed to clarify the role of this new drug (alone or in combination with dopaminergic drugs) in the algorithm of therapy of pituitary adenomas.

\section{References}

1 Missale C, Nash SR, Robinson SW, Jaber M \& Caron MG. Dopamine receptors: from structure to function. Physiological Reviews 1998 78 189-225.

2 Guillemin R \& Gerich JE. Somatostatin: physiological and clinical significance. Annual Review of Medicine 197627 379-388.

3 Greenman Y \& Melmed S. Expression of three somatostatin receptor subtypes in pituitary adenomas: evidence for preferential SSTR 5 expression in the mammosomatotroph linage. Journal of Clinical Endocrinology and Metabolism 1994 79 724-729.

4 Greenman Y \& Melmed S. Heterogeneous expression of two somatostatin receptor subtypes in pituitary tumors. Journal of Clinical Endocrinology and Metabolism 199478 398-403.

5 Bression D, Brandi AM, Martres MP, Nousbaum A, Cesselin F, Racadot J \& Peillon F. Dopaminergic receptors in human prolactinsecreting adenomas: a quantitative study. Journal of Clinical Endocrinology and Metabolism 198051 1037-1044.

6 Bression D, Brandi AM, Nousbaum A, Le Dafniet M, Racadot J \& Peillon F. Evidence of dopamine receptors in huam growth 
hormone $(\mathrm{GH})$-secreting adenomas with concomitant study of dopamine inhibition of $\mathrm{GH}$ secretion in a perfusion system. Journal of Clinical Endocrinology and Metabolism 1982 55 589-593.

7 Bevan JS \& Burke CW. Non-functioning pituitary adenomas do not regress during bromocriptine therapy but possess membranebound dopamine receptors which bind bromocriptine. Clinical Endocrinology 198625 561-572.

8 Hofland LJ \& Lamberts SW. Somatostatin receptor subtype expression in human tumors. Annals of Oncology 200112 (Suppl. 2) S31-S36.

9 De Herder WW \& Lamberts SWJ. Somatostatin and somatostatin analogues: diagnostic and therapeutic uses. Current Opinion in Oncology $20021453-57$.

10 Lamberts SWJ. Somatostatin analogs: their role in the treatment of growth hormone hypersecretion and excessive body growth. Growth Regulation 19911 3-10.

11 Stefaneanu L, Kovacs K. Horvath E, Buchfelder M, Fahlbusch R \& Lancranjan L. Dopamine D2 receptor gene expression in human adenohypophysial adenomas. Endocrine 2001 14 329-336.

12 Webster J, Piscitelli G, Polli A. Ferrari CI, Ismail I \& Scanlon MF. A comparison of cabergoline and bromocriptine in the treatment of hyperprolactinemic amenorrhea. Cabergoline Comparative Study Group New England Journal of Medicine 1994331 904-909.

13 Colao A. Di Sarno A. Sarnacchiaro F, Ferone D, Di Renzo G, Merola B. Annunziato L \& Lombardi G. Prolactinomas resistant to standard dopamine agonists respond to chronic cabergoline treatment. Journal of Clinical Endocrinology and Metabolism 1997 $82876-883$.

14 Pivonello R, Ferone D, de Herder WW. Kros JM. De Caro ML. Arvigo M, Annunziato L, Lombardi G, Colao A. Hofland LJ \& Lamberts SW. Dopamine receptor expression and function in corticotroph pituitary tumors. Journal of Clinical Endocrinology and Metabolism $2004892452-2462$.

15 Rocheville M, Lange DC, Kumar U, Patel SC, Patel RC \& Patel YC. Receptors for dopamine and somatostatin: formation of heterooligomers with enhanced functional activity. Science $2000 \mathbf{2 8 8}$ 154-157.

16 Colao A, Ferone D, Marzullo P. Di Sarno A, Cerbone G, Sarnacchiaro F, Cirillo S, Merola B \& Lombardi G. Effect of different domaminergic agents in the treatment of acromegaly. Journal of Clinical Endocrinology and Metabolism 199782 518-523.

17 Flogstad AK, Halse J, Grass P, Abisch E, Djoseland O, Kutz K, Bodd E \& Jervell J. A comparison of octreotide, bromocriptine, or a combination of both drugs in acromegaly. Journal of Clinical Endocrinology and Metabolism 199479 461-465.

18 Renner U, Mojto J, Lange M, Muller OA, von Werder K \& Stalla GK. Effect of bromocriptine and SMS 201-995 on growth of human somatotrophic and non-functioning pituitary adenoma cells in vitro. European Journal of Endocrinology 1994130 80-91.

19 Wagenaar AH, Harris AG, van der Lely AJ \& Lamberts SW. Dynamics of the acute effects of octreotide, bromocriptine and both drugs in combination on growth hormone secretion in acromegaly. Acta Endocrinologica 1991125 637-642.

20 Sadoul JL. Thyss A \& Freychet P. Invasive mixed growth hormone/prolactin secreting pituitary tumor: complete shrinking by octreotide and bromocriptine, and lack of tumor growth relapse 20 months after octreotide withdrawal. Acta Endocrinologica 1992 126 179-183.

21 Cremonini N, Graziano E, Chiarini V, Sforza A \& Zampa GA. Atypical McCune-Albright syndrome associated with growth hormone-prolactin pituitary adenoma: natural history, longterm follow-up, and SMS 201-995-bromocriptine combined treatment results. Journal of Clinical Endocrinology and Metabolism 199275 1166-1169.

22 Lombardi G, Colao A, Ferone D, Sarnacchiaro F, Marzullo P, Di Sarno A, Rossi E \& Merola B. CV 205-502 treatment in therapy-resistant acromegalic patients. European Journal of Endocrinology 1995132 559-564.
23 Marzullo P. Ferone D, Di Somma C. Pivonello R, Filippella M, Lombardi G \& Colao A. Efficacy of combined treatment with lanreotide and cabergoline in selected therapy-resistant acromegalic patients. Pituitary $19991115-120$.

24 Cozzi R, Attanasio R, Lodrini S \& Lasio G. Cabergoline addition to depot somatostatin analogues in resistant acromegalic patients: efficacy and lack of predictive value of prolactin status. Clinical Endocrinology $200461209-215$.

25 Selvarajah D, Webster J. Ross R \& Newell-Price J. Effectiveness of adding dopamine agonist therapy to long-acting somatostatin analogues in the management of acromegaly. European Journal of Endocrinology $2005152569-574$.

26 Jaffe CA \& Barkan AL. Treatment of acromegaly with dopamine agonists. Endocrinology and Metabolism Clinics of North America $199221713-735$.

27 Abs R, Verhelst J. Maiter D, Van Acker K, Nobels F, Coolens JL, Mahler C \& Beckers A. Cabergoline in treatment of acromegaly: a study in 54 patients. Journal of Clinical Endocrinology and Metabolism 199883 374-378.

28 Howlett TA, Robertson IJA, Liddicoat A. Acromegaly: shrinkage of macroadenomas with cabergoline (abstract). Proceedings of the Endocrine Society 79th Annual Meeting. Mineapolis June 1997.

29 Freda PU, Katznelson L, van der Lely AJ, Reyes CM, Zhao S \& Rabinowtiz D. Long-acting somatostatin analog therapy of acromegaly: a meta-analysis. Journal of Clinical Endocrinology and Metabolism $2005904465-4473$.

30 Lamberts SW, Zweens M, Verschoor L \& del Pozo E. A comparison among the growth hormone-lowering effects in acromegaly of the somatostatin analog SMS 201-995, bromocriptine, and the combination of both drugs. Journal of Clinical Endocrinology and Metabolism 198663 16-19.

31 Fredstorp L, Kutz K \& Werner S. Treatment with octreotide and bromocriptine in patients with acromegaly: an open pharmacodynamic interaction study. Clinical Endocrinology $1994 \mathbf{4 1}$ 103-108.

32 Ferone D, Pivonello R, Lastoria S, Faggiano A, Del Basso de Caro ML, Cappabianca P. Lombardi G \& Coalo A. In vivo and in vitro effects of octreotide, quinagolide and cabergoline in four hyperprolactinaemic acromegalics: correlation with somatostatin and dopamine D2 receptor scintigraphy. Clinical Endocrinology 200154 469-477.

33 Zatelli MC, Piccin D, Tagliati F, Bottoni A, Ambrosio MR, Margutti A, Scanarini M, Bondanelli M, Culler MD \& degli Uberti EC. Dopamine receptor subtype 2 and somatostatin receptor subtype 5 expression influences somatostatin analogs effects on human somatotroph pituitary adenomas in vitro. Journal of Clinical Endocrinology and Metabolism 200535 333-341.

34 Klibanski A. Non-secreting pituitary tumors. Endocrinology and Metabolism Clinics of North America 198716 793-804.

35 Koga M. Nakao H. Arao M. Stato B. Noma K. Morimoto Y, Kishimoto S, Mori S \& Uozumi T. Demostration of specific dopamine receptors on human pituitary adenomas. Acta Endocrinologica 1987114 595-602.

36 Bevan JS. Webster J, Burke CW \& Scanlon MF. Dopamine agonists and pituitary tumor shrinkage. Endocrine Reviews 199213 221-240.

37 Grossman A. Ross R. Charlesworth M. Adams CB. Wass JA, Doniach I \& Besser GM. The effect of dopamine agonist therapy on large functionless pituitary tumours. Clinical Endocrinology 1985 22 679-686.

38 Ferone D, Lastoria S, Colao A, Varrella P. Cerbone G, Acampa W, Merola B, Salvatore M \& Lombardi G. Correlation of scintigraphic results, using 123I-methoxybenzamide with hormone levels and tumor size response to quinagolide in patients with pituitary adenomas. Journal of Clinical Endocrinology and Metabolism 1998 $83248-252$.

39 Hedner P \& Valdemarsson S. Reduced size of a hormonally silent pituitary adenoma during treatment with CV 205-502, a new dopamine agonist mainly stimulating D2 receptors. Neurosurgery 198925 948-950. 
40 Nobels FR, de Herder WW, van den Brink WM, Kwekkeboom DJ Hofland LJ. Zuyderwijk J, de Jong FH \& Lamberts SW. Long-term treatment with the dopamine agonist quinagolide of patients with clinically non-functioning pituitary adenoma. European Journal of Endocrinology 2000143 615-621.

41 Lamberts SW, Uitterlinden P \& Del Pozo E. SMS 201-995 induces a continuous decline in circulating growth hormone and somatomedin-C levels during therapy of acromegalic patients for over two years. Journal of Clinical Endocrinology and Metabolism $198765703-710$.

42 Lamberts SW, Bakker WH, Reubi JC \& Krenning EP. Somatostatin receptor imaging in localization of endocrine tumors. New England Journal of Medicine 1990323 1246-1249.

43 Faglia G, Bazzoni N, Spada A, Arosio M, Ambrosi B, Spinelli F, Sara R, Bonino C \& Lunghi $\mathrm{F}$. In vivo detection of somatostatin receptors in patients with functionless pituitary adenomas by means of a radioiodinated analog of somatostatin ([131] SDZ 204-090). Journal of Clinical Endocrinology and Metabolism 199173 850-856.

44 Plockinger U, Reichel M, Fett U, Saeger W \& Quabbe HJ. Preoperative octreotide treatment of growth hormone-secreting and clinically nonfunctioning pituitary macroadenomas: Effect on tumor volume and lack of correlation with immohistochemistry and somatostatin receptor scintigraphy. Journal of Clinical Endocrinology and Metabolism 199474 1416-1423.

45 Colao A, Lastoria S, Ferone D, Varrella P, Marzullo P, Pivonello P, Cerbone G, Acampa W, Salvatore M \& Lombardi G. The pituitary uptake of 111-DTPA-D-Phe1-octreotide in the normal pituitary and in pituitary adenomas. Journal of Endocrinological Investigation 199922 176-183.

46 Warnet A, Harris AG, Renard E, Martin D, James-Deidier A \& Chaumet-Riffaud P. A prospective multicenter trial of octreotide in 24 patients with visual defects caused by nonfunctioning and gonadotropin-secreting pituitary adenomas. The French Multicenter Octreotide Study Group. Neurosurgery 199741 786-797.

47 Vance ML, Ridgeway EC \& Thorner MO. Follicle-stimulating hormone and a-subunit-secreting pituitary tumor treated with bromocriptine. Journal of Clinical Endocrinology and Metabolism $198561580-584$.

48 Kwekkeboom DJ \& Lamberts SW. Long-term treatment with the dopamine agonist CV 205-502 of patients with a clinically non-functioning, gonadotroph, or a-subunit secreting pituitary adenoma. Clinical Endocrinology 199236 171-176.

49 Ferone D, Lastoria S, Colao A, Varrella P, Cerbone G, Acampa W, Merola B, Salvatore M \& Lombardi G. Correlation of scintigraphic results using 123I-metoxybenzamide with hormone levels and tumor size response to quinagolide in patients with pituitary adenomas. Journal of Clinical Endocrinology and Metabolism 1998 $83248-252$.

50 Lohmann T, Trantakis C, Biesold M, Prothmann S, Guenzel S, Schober R \& Paschke R. Minor tumor shrinkage in nonfunctioning pituitary adenomas by long-term treatment with the dopamine agonist cabergoline. Pituitary 20014 173-178.
51 Pivonello R, Martone C, Filippella M, Cavallo LM, Di Somma C, Cappabianca P, Colao A, Annunziato L \& Lombardi G. Dopamine receptor expression and function in clinically nonfunctioning pituitary tumors: comparison with the effectiveness of cabergoline treatment. Journal of Clinical Endocrinology and Metabolism 2004 89 1674-1683.

52 Liuzzi A, Dallabonzana D \& Oppizzi G. GIs there a real medical treatment for the 'non-secreting' pituitari adenomas? (abstract) Journal of Endocrinological Investigation 199114 (suppl. 1) 18.

53 De Bruin TW, Kwekkeboom DJ, Van't Verlaat JW, Reubi JC, Krenning EP, Lamberts SW \& Croughs RJ. Clinically non functioning pituitary adenoma and octreotide response to longterm high dose treatment, and studies in vitro. Journal of Clinical Endocrinology and Metabolism 199275 1310-1317.

54 Warnet A, Timsit J, Chanson P, Guillausseau PJ, Zamfirescu F, Harris AG, Derome P, Cophignon J \& Lubetzki J. The effect of somatostatin analogue on chiasmal dysfunction from pituitary macroadenomas. Journal of Neurosurgery 198971 687-690.

55 Andersen M, Bjerre P, Schroder HD, Edal A, Hoilund-Carlsen PF, Pedersen $\mathrm{PH} \&$ Hagen $\mathrm{C}$. In vivo secretory potential and the effect of combination therapy with octreotide and cabergoline in patients with clinically non-functioning pituitary adenomas. Clinical Endocrinology 2001 54 23-30.

56 Ducati A, Losa M, Fava E, Cenzato M \& Giovannelli M. Acute effects on visual function of a somatostatin analog (SMS 201-995) evaluated using a neurophsiological approach (abstrct). Journal of Endocrinological Investigation 199114 (suppl. 1) 120.

57 Colao A, Ferone D, Lastoria S, Cerbone G, Di Sarno A, Di Somma C, Lucci R \& Lombardi G. Hormone levels and tumor size response to quinagolide and cabergoline in patients with prolactin-secreting and clinically nonfunctioning pituitary adenomas: predictive value of pituitary. scintigraphy with 123I-methoxybenzamide. Clinical Endocrinology $2000 \mathbf{5 2} 437-445$.

58 van der Hoek J, de Herder WW, Feelders RA, van der Lely AJ, Uitterlinden $\mathrm{P}$, Boerlin V, Bruns C, Poon KW, Lewis I, Weckbecker G, Krahnke T, Hofland LJ \& Lamberts SW. A single-dose comparison of the acute effects between the new somatostatin analog SOM230 and octreotide in acromegalic patients. Journal of Clinical Endocrinology and Metabolism $200489638-645$.

59 Arnaldi G, Polenta B, Cardinaletti M \& Boscaro M. Potential indications for somatostatin analogs in Cushing's syndrome. Journal of Endocrinological Investigation 200528 (Suppl. 11) 106-110.

Received 26 December 2006

Accepted 18 January 2007 